Diabetologia (1992) 35: 1074-1079

\title{
Circadian variation of blood pressure in patients with diabetic nephropathy
}

\author{
K.W.Hansen, M. Mau Pedersen, S. M.Marshall, J.S. Christiansen and C. E. Mogensen \\ Medical Department M (Diabetes and Endocrinology), Kommunehospitalet, Aarhus, Denmark
}

\begin{abstract}
Summary. The association between diurnal blood pressure variation and diabetic nephropathy was assessed in four groups of Type 1 (insulin-dependent) diabetic patients who underwent 24 -h ambulatory blood pressure monitoring using an oscillometric technique. Patients with nephropathy, who had never been treated for hypertension (group $\mathrm{D}_{3}, n=13$ ), were individually matched for age, sex and diabetes duration to a group of microalbuminuric patients $\left(D_{2}, n=26\right)$, to normoalbuminuric patients $\left(\mathrm{D}_{1}, n=26\right)$ and to healthy control subjects $(\mathrm{C}, n=26)$. Group $\mathrm{D}_{3}$ was also compared to patients with advanced nephropathy receiving treatment for hypertension, mainly a combination of angiotensin converting enzyme inhibitors, metoprolol and diuretics $\left(\mathrm{D}_{4}, n=11\right)$. In group $\mathrm{D}_{3} 24$-h diastolic blood pressure $(85 \pm 8 \mathrm{mmHg}$ ) was comparable to the results obtained in $\mathrm{D}_{4}(85 \pm 8 \mathrm{~mm} \mathrm{Hg})$ but significantly higher than in $\mathrm{D}_{2}(78 \pm 7 \mathrm{~mm} \mathrm{Hg}), \mathrm{D}_{1}$ $(73 \pm 7 \mathrm{~mm} \mathrm{Hg})$ and $\mathrm{C}(73 \pm 7 \mathrm{mmHg}, p<0.05$, Tukey's test). The night/day ratio of diastolic blood pressure was higher in $D_{3}(86 \pm 5 \%)$ and $D_{2}(85 \pm 7 \%)$ than in $C$
\end{abstract}

$(80 \pm 7 \%, p<0.02)$. This ratio was also elevated in group $\mathrm{D}_{4}$ $(94 \pm 8 \%)$ compared to $\mathrm{D}_{3}(p<0.05)$ corresponding to a marked smoothing of the diurnal blood pressure curve. The 24-h heart rate (beats per min) was significantly elevated in $\mathrm{D}_{3}(84 \pm 8)$ and $\mathrm{D}_{2}(80 \pm 10)$ compared with $\mathrm{C}(73 \pm 11$, $p<0.05$ Tukey's test), suggesting the presence of parasympathetic neuropathy. In conclusion the normal circadian variation of blood pressure was moderately disturbed in a group of microalbuminuric patients and patients with less advanced overt nephropathy. Patients with advanced diabetic nephropathy receiving antihypertensive therapy showed a marked reduction of nocturnal blood pressure fall, which can only be identified by the application of ambulatory blood pressure measurements to verify the 24 -h effectiveness of blood pressure control.

Key words: Type 1 (insulin-dependent) diabetes mellitus, diabetic nephropathy, ambulatory blood pressure, circadian variation.
Diabetic nephropathy is a severe complication which not only leads to premature death from renal failure [1] but is also strongly associated with increased cardiovascular mortality [2]. Antihypertensive treatment impedes progression of the disease $[3,4]$ and improves life expectancy [5]. Although a low-protein diet may be of added benefit [6] control of blood pressure remains the single most important treatment modality. Ambulatory 24-h blood pressure measurement is now a well-established technique which allows the physician to document the effectiveness of treatment during sleep and everyday activities [7]. Recent studies encompassing a combined population of Type 2 (non-insulin-dependent) and Type 1 (insulindependent) diabetic patients have demonstrated a blunted diurnal variation of blood pressure in patients suffering from diabetic autonomic neuropathy as defined by a battery of bedside tests [8-10]. The clinical significance of impaired reduction of nocturnal blood pressure may be of particular importance in diabetic nephropathy since a positive association exists between autonomic neuropathy and stages of renal disease [11]. We hypothesise that a similar association exists between stages of renal disease and loss of nocturnal blood pressure reduction.

Ambulatory blood pressure was studied in two groups of Type 1 diabetic patients with established diabetic nephropathy, one group receiving treatment and one group not receiving treatment for hypertension. Diabetic patients with normal urinary albumin excretion (UAE), patients with microalbuminuria, and healthy control subjects were included for comparison.

\section{Subjects and methods}

Type 1 diabetic patients were grouped by stage of renal disease using previously published cirteria [12]. The presence of diabetic nephropathy in patients who had never received antihypertensive or 
Table 1. Clinical data of Type 1 (insulin-dependent) diabetic patients and healthy control subjects studied

\begin{tabular}{|c|c|c|c|c|c|c|}
\hline & $\mathrm{C}$ & $\mathrm{D}_{1}$ & $\mathrm{D}_{2}$ & $\mathrm{D}_{3}$ & ANOVA & $\mathrm{D}_{4}$ \\
\hline Male/female & $18 / 8$ & $18 / 8$ & $18 / 8$ & $9 / 4$ & NS & $9 / 2$ \\
\hline Age (years) & $\begin{array}{l}33 \pm 10 \\
(22-53)\end{array}$ & $\begin{array}{l}36 \pm 9 \\
(22-54)\end{array}$ & $\begin{array}{l}32 \pm 10 \\
(20-49)\end{array}$ & $\begin{array}{l}34 \pm 9 \\
(23-51)\end{array}$ & NS & $\begin{array}{l}41 \pm 9 \\
(29-54)\end{array}$ \\
\hline $\begin{array}{l}\text { Diabetes } \\
\text { duration (years) }\end{array}$ & & $\begin{array}{l}20 \pm 6 \\
(11-31)\end{array}$ & $\begin{array}{l}19 \pm 6 \\
(10-28)\end{array}$ & $\begin{array}{l}21 \pm 7 \\
(10-32)\end{array}$ & NS & $\begin{array}{l}26 \pm 7 \\
(16-36)\end{array}$ \\
\hline $\begin{array}{l}\text { Body mass index } \\
\left(\mathrm{kg} / \mathrm{m}^{2}\right)\end{array}$ & $\begin{array}{l}23.7 \pm 3.3 \\
(18.9-35.0)\end{array}$ & $\begin{array}{l}24.3 \pm 3.1 \\
(20.2-32.4)\end{array}$ & $\begin{array}{l}24.3 \pm 3.1 \\
(18.9-32.1)\end{array}$ & $\begin{array}{l}22.5 \pm 1.3 \\
(20.4-24.2)\end{array}$ & NS & $\begin{array}{l}23.7 \pm 2.8 \\
(19.4-27.8)\end{array}$ \\
\hline Insulin dose (U/kg) & & $\begin{array}{l}0.66 \pm 0.14 \\
(0.38-0.92)\end{array}$ & $\begin{array}{l}0.71 \pm 0.24 \\
(0.32-1.39)\end{array}$ & $\begin{array}{l}0.66 \pm 0.15 \\
(0.50-1.11)\end{array}$ & NS & $\begin{array}{l}0.61 \pm 0.30 \\
(0.33-1.45)\end{array}$ \\
\hline $\mathrm{HbA}_{t c}(\%)$ & $\begin{array}{l}5.2 \pm 0.54 \\
(4.0-6.2)\end{array}$ & $\begin{array}{l}8.7 \pm 1.6 \\
(6.3-11.2)\end{array}$ & $\begin{array}{l}9.3 \pm 1.4 \\
(7.2-13.5)\end{array}$ & $\begin{array}{l}8.7 \pm 1.4 \\
(5.5-10.5)\end{array}$ & NS & $\begin{array}{l}9.5 \pm 1.3 \\
(7.7-11.9)\end{array}$ \\
\hline $\begin{array}{l}\text { Serum creatinine } \\
(\mu \mathrm{mol} / \mathrm{l})\end{array}$ & $\begin{array}{l}83 \\
(61-107)\end{array}$ & $\begin{array}{l}81 \\
(55-116)\end{array}$ & $\begin{array}{l}76 \\
(53-110)\end{array}$ & $\begin{array}{l}99^{\mathrm{c}, \mathrm{d}} \\
(76-183)\end{array}$ & $p<0.01$ & $\begin{array}{l}144^{e} \\
(102-252)\end{array}$ \\
\hline $\begin{array}{l}\text { Urinary albumin excretion }{ }^{b} \\
(\mu \mathrm{g} / \mathrm{min})\end{array}$ & $\begin{array}{l}4.7 \times / \div 1.9 \\
(1.6-25.2)\end{array}$ & $\begin{array}{l}4.8 x / \div 1.9 \\
(1.1-15.7)\end{array}$ & $\begin{array}{l}51.5 x / \div 2.1 \\
(20.2-198.3)\end{array}$ & $\begin{array}{l}821 x / \div 2.2 \\
(207-2730)\end{array}$ & NA & $\begin{array}{l}817 x / \div 3.3 \\
(59-4936)\end{array}$ \\
\hline $\begin{array}{l}\text { Retinopathy } \\
\text { (normal/background } \\
\text { proliferative) }\end{array}$ & & $12 / 13 / 1$ & $4 / 18 / 4$ & $2 / 7 / 4$ & $p<0.05^{\mathrm{f}}$ & $0 / 2 / 9$ \\
\hline
\end{tabular}

Values are mean $\pm \mathrm{SD}$ and (range), ${ }^{a}$ median and (range) or ${ }^{\mathrm{b}}$ geometric mean $(\mathrm{x} / \div$ tolerance factor $)$.

$\mathrm{C}$, Control subjects; $\mathrm{D}_{1}$, normoalbuminuric patients; $\mathrm{D}_{2}$, microalbuminuric patients; $D_{3}$, diabetic patients with nephropathy; $D_{4}$,

diuretic treatment (group $\mathrm{D}_{3}, n=13$ ) was accepted if diabetes duration was more than 10 years and UAE was greater than $200 \mu \mathrm{g} / \mathrm{min}$ as well as the geometric mean in at least two of three timed ovemight urine samples collected within 1 week. The patients in group $\mathrm{D}_{3}$ represent all those not taking antihypertensive treatment who regularly consult our out-patient clinic as well as the patients reintroduced to the clinic during a 2-year period. None of these patients were prescribed a low-protein diet.

Each diabetic patient from group $D_{3}$ was matched (without knowledge of blood pressure) for sex, age and diabetes duration to two microalbuminuric diabetic patients (group $\mathrm{D}_{2}, n=26$ ) $(20 \mu \mathrm{g} / \mathrm{min}<\mathrm{UAE}<200 \mu \mathrm{g} / \mathrm{min}$ ), two normoalbuminuric diabetic patients (group $\left.\mathrm{D}_{1}, n=26\right)(\mathrm{UAE}<20 \mu \mathrm{g} / \mathrm{min}$ ) and two healthy control subjects (group $C, n=26$ ). Patients and subjects in the matching groups had participated in a previously described study [13].

A further group of patients with diabetic nephropathy taking antihypertensive treatment (group $\mathrm{D}_{4}, n=11$ ) were also examined. Patients were included in this group if duration of antihypertensive treatment (median 52, range 12-132 months) was longer than 1 year and if hypertension was the indication for commencement of treatment according to the records i.e. diastolic blood pressure above $95 \mathrm{~mm} \mathrm{Hg}$ measured in the clinic by sphygmomanometer. One patient in group $D_{3}$ was also included in $D_{4}$ and restudied after 14 months of treatment for hypertension. As antihypertensive therapy we used angiotensin converting enzyme inhibitors (ACE-inhibitors) in combination with metoprolol and diuretics $(n=6)$, ACE-inhibitors in combination with diltiazem and diuretics $(n=1)$, ACE-inhibitors in combination with diuretics $(n=3)$, and metoprolol combined with diuretics $(n=1)$. The ACE-inhibitors used were enalapril once per day, median dose $20 \mathrm{mg}$ (range 5-20 mg) or captopril two times per day, total dose $75 \mathrm{mg}$ ( $50-100 \mathrm{mg}$ ). Metoprolol was given at a total dose of $150 \mathrm{mg}(50-200 \mathrm{mg})$ in the morning as a sustained-release preparation except in tow patients, one of whom received a standard preparation two times per day and one who received two daily doses of the sustained-release drug. Diuretics were thiazides $(n=4)$ or furosemide $(n=7)$.

It is well-known that antihypertensive treatment in diabetic ncphropathy may reduce UAE to a subclinical level and thus interferes with traditional criteria for diagnosing nephropathy [14]. One pa- diabetic patients with nephropathy and antihypertensive treatment; NS, not significant; NA, not applicable; ANOVA, analysis of variance. ${ }^{c d} p<0.05$ vs $D_{1}$, and $D_{2}$ (Tukey's test, respectively); ${ }^{\mathrm{e}} p<0.001$ vs $\mathrm{D}_{3}$ (Student $t$-test); ${ }^{\mathrm{f}}$ Rank sum test

tient with elevated serum creatinine $(171 \mu \mathrm{mol} / \mathrm{l})$ and UAE of $59 \mu \mathrm{g} /$ min was included in group $\mathrm{D}_{4}$. This patient had persistent albumin positive urine (Albustix, Ames, Bayer diagnostics, Bridgend, UK) at the initiation of antihypertensive therapy, and UAE was succesively reduced during the following 6 years while serum creatinine increased.

Twenty-four hour ambulatory blood pressure was measured oscillometrically by a portable lightweight monitor (Spacelabs 90202 , Redmond, Wa, USA) fulfilling the standards of botb the American Association for the Advancement of Medical Instruments and the British Hypertension Society [15]. The monitor was programmed to take measurements every $20 \mathrm{~min}$ during the day and every hour from 24.00 to 06.00 hours. Heart rate was measured as the frequency of oscillations in the cuff and thus recorded simultaneously with blood pressure. After the equipment was demonstrated in the laboratory, two measurements were activated to accustom the patient to the technique, and then three measurements were recorded with the patient sitting and the arm supported. The mean of these last three measurements is termed the clinic blood pressure. All five measurements obtained in the laboratory were deleted from the record before calculating $24 \mathrm{~h}$ blood pressures. Day and night blood pressures and heart rates were calculated as the mean of hourly mean values based on each patient's self-recorded time for going to bed and rising in the morning.

UAE was measured by radioimmunoassay [16], $\mathrm{HbA}_{1 c}$ by high pressure liquid chromatography [17] and serum creatinine by a modificated Jaffés method on a SMAC-III autoanalyser (Téchnicon, Terrytown, NY, USA) using an end-point technique. Retinopathy was assessed by fundoscopy. Patients gave their informed consent and the study was approved by the local ethics committee.

\section{Statistical analysis}

Results for UAE were log transformed to obtain normal distribution before analysis and results are presented as geometric mean and tolerance factor. Group $\mathrm{D}_{3}$ was compared to the three matching groups by analysis of variance in cases of homogeneity of variance (Bartlett's test). Non-continuous variables were compared by a rank sum test. Differences between groups were assessed by an unpaired 
Table 2. Blood pressure and heart rate of Type 1 (insulin-dependent) diabetic patients and healthy control subjects

\begin{tabular}{|c|c|c|c|c|c|c|c|}
\hline & & $\mathrm{C}$ & $\mathrm{D}_{1}$ & $\mathrm{D}_{2}$ & $\mathrm{D}_{3}$ & ANOVA & $\mathrm{D}_{4}$ \\
\hline $\begin{array}{l}\text { Systolic blood } \\
\text { pressure }\end{array}$ & $\begin{array}{l}\text { Clinic (mm Hg) } \\
\text { Daytime (mm Hg) } \\
\text { Night-time }(\mathrm{mm} \mathrm{Hg}) \\
\text { Night/day ratio }(\%) \\
24-\mathrm{h}(\mathrm{mm} \mathrm{Hg})\end{array}$ & $\begin{array}{l}123 \pm 11 \\
124 \pm 9 \\
108 \pm 9 \\
87.5 \pm 5.9 \\
119 \pm 9\end{array}$ & $\begin{array}{c}126 \pm 10 \\
128 \pm 10 \\
112 \pm 11 \\
88.1 \pm 6.1 \\
123 \pm 10 \\
\end{array}$ & $\begin{array}{l}132 \pm 9^{\mathrm{a}} \\
137 \pm 11^{\mathrm{a}, \mathrm{b}} \\
123 \pm 11^{\mathrm{a}, \mathrm{b}} \\
89.7 \pm 6.3 \\
132 \pm 10^{\mathrm{a}, \mathrm{b}} \\
\end{array}$ & $\begin{array}{l}142 \pm 11^{a_{,}, b_{1} c} \\
142 \pm 12^{a, b} \\
128 \pm 12^{a, b} \\
90.4 \pm 6.0 \\
137 \pm 11^{a_{,}, b}\end{array}$ & $\begin{array}{l}p<0.0001 \\
p<0.0001 \\
p<0.0001 \\
\mathrm{NS} \\
p<0.0001\end{array}$ & $\begin{array}{l}142 \pm 13 \\
141 \pm 13 \\
137 \pm 17 \\
97.6 \pm 8.1^{\mathrm{d}} \\
140 \pm 14 \\
\end{array}$ \\
\hline $\begin{array}{l}\text { Diastolic blood } \\
\text { pressure }\end{array}$ & $\begin{array}{l}\text { Clinic }(\mathrm{mm} \mathrm{Hg}) \\
\text { Daytime }(\mathrm{mm} \mathrm{Hg}) \\
\text { Night-time }(\mathrm{mmHg}) \\
\text { Night/day ratio }(\%) \\
24 \mathrm{~h}(\mathrm{~mm} \mathrm{Hg})\end{array}$ & $\begin{array}{l}76 \pm 10 \\
78 \pm 7 \\
62 \pm 7 \\
79.8 \pm 7.4 \\
73 \pm 7\end{array}$ & $\begin{array}{l}77 \pm 8 \\
78 \pm 7 \\
65 \pm 8 \\
83.1 \pm 8.6 \\
73 \pm 7\end{array}$ & $\begin{array}{l}79 \pm 7 \\
82 \pm 7 \\
70 \pm 8^{\mathrm{a}} \\
85.0 \pm 7.3 \\
78 \pm 7^{\mathrm{a}}\end{array}$ & $\begin{array}{l}89 \pm 8^{a, b, c} \\
90 \pm 8^{a, b, c} \\
77 \pm 10^{a, b, c} \\
86.0 \pm 5.1 \\
85 \pm 8^{a, b, c}\end{array}$ & $\begin{array}{l}p<0.001 \\
p<0.0001 \\
p<0.0001 \\
p<0.05 \\
p<0.0001\end{array}$ & $\begin{array}{l}87 \pm 9 \\
86 \pm 8 \\
81 \pm 11 \\
93.5 \pm 8.1^{d} \\
85 \pm 8\end{array}$ \\
\hline Heart rate & $\begin{array}{l}\text { Daytime (beats per min) } \\
\text { Night-time (beats per min) } \\
\text { Night/day ratio (\%) } \\
\text { 24-h (beats per min) } \\
\text { Night hours }(n)\end{array}$ & $\begin{array}{l}78 \pm 12 \\
64 \pm 12 \\
82.1 \pm 10.0 \\
73 \pm 11 \\
8(6-10)\end{array}$ & $\begin{array}{l}82 \pm 9 \\
69 \pm 10 \\
83.9 \pm 9.6 \\
78 \pm 8 \\
8(5-11)\end{array}$ & $\begin{array}{l}86 \pm 10^{\mathrm{a}} \\
67 \pm 10 \\
77.4 \pm 7.4 \\
80 \pm 10^{\mathrm{a}} \\
7(6-12)\end{array}$ & $\begin{array}{c}89 \pm 9^{\mathrm{a}} \\
74 \pm 8^{\mathrm{a}} \\
83.9 \pm 9.3 \\
84 \pm 8^{\mathrm{a}} \\
7(5-12)\end{array}$ & $\begin{array}{l}p<0.01 \\
p<0.05 \\
p<0.05 \\
p<0.01 \\
\text { NS }\end{array}$ & $\begin{array}{c}82 \pm 12 \\
78 \pm 12 \\
94.7 \pm 5.3^{\circ} \\
81 \pm 11 \\
7(6-13)\end{array}$ \\
\hline
\end{tabular}

Values are mean $\pm \mathrm{SD}$ or median and (range). ${ }^{\mathrm{a}, b^{b}, c} p<0.05 \mathrm{vs} \mathrm{C}, \mathrm{D}_{1}$, and $D_{2}$, respectively (Tukey's test).

d, e $p<0.05, p<0.001$ vs $\mathrm{D}_{3}$ (Student $t$-test). NS, Not significant; $\mathrm{C}$, control subjects, $D_{1}$, normoalbuminuric patients; $D_{2}$, microalbu-

$t$-test with and without Tukey's modification for correction for multiple comparison. In cases of non-homogeneity of variance a non-parametric test (Kruskall-Wallis) was applied with Dunn's correction for multiple testing. Group $\mathrm{D}_{4}$ was compared to group $\mathrm{D}_{3}$ only by an unpaired $t$-test and Fisher's exact test. Multiple stepwise selection was performed as a forward selection procedure. A twotailed $p$ value less than 0.05 was accepted as statistically significant. All statistical analyses were done by the program Statgraphics (STCS, Rockville, Md., USA).

\section{Results}

Groups $\mathrm{D}_{1}, \mathrm{D}_{2}$ and $\mathrm{D}_{3}$ were well-matched for age, sex and duration of diabetes (Table 1). In addition $\mathrm{HbA}_{1 \mathrm{c}}$, insulin dose and body mass index were also comparable. Serum. creatinine was significantly higher in $D_{3}$ compared to $D_{1}$ and $\mathrm{D}_{2}$. Two patients in $\mathrm{D}_{3}$ had a serum creatinine above the upper normal limit $(120 \mu \mathrm{mol} / 1)$ in our laboratory. Patients in group $\mathrm{D}_{4}$ were slightly older than those in $\mathrm{D}_{3}$ ( $41 \pm 9$ vs $34 \pm 9$ years), with longer diabetes duration ( $26 \pm 7$ vs $21 \pm 7$ years) and higher mean value of $\mathrm{Hb} \mathrm{A}_{1 \mathrm{c}}$ $(9.5 \pm 1.3$ vs $8.7 \pm 1.4 \%)$, however the differences did not reach the accepted level for statistical significance $(p=0.09,0.08$ and 0.17 respectively). Retinopathy was more advanced in patients with nephropathy.

Blood pressure results are given in Table 2. Three patients in $\mathrm{D}_{3}$ but none in groups $\mathrm{C}, \mathrm{D}_{1}$, or $\mathrm{D}_{2}$ had a diastolic clinic blood pressure above $95 \mathrm{~mm} \mathrm{Hg}$. Both the clinic and ambulatory diastolic blood pressure was significantly higher in $\mathrm{D}_{3}$ than in groups $\mathrm{C}, \mathrm{D}_{1}$ and $\mathrm{D}_{2}(p<0.05)$. Group $\mathrm{D}_{4}$ had clinic and ambulatory blood pressures comparable with $\mathrm{D}_{3}$.

The question of differences in diurnal variation of blood pressure was addressed by calculating the night/day ratio. Analysis of variance revealed significant $(p<0.05)$ inter-group differences for diastolic ratios which increased stepwise from $\mathrm{C}(79.8 \pm 7.4 \%)$ to $\mathrm{D}_{3}$ $(86.0 \pm 5.1 \%)$. The intra-group variation however was high and when allowance for the correction for multiple testing was made no comparison between two groups was minuric patients; $D_{3}$, diabetic patients with nephropathy; $D_{4}$ diabetic patients with nephropathy and antihypertensive treatment; ANOVA, analysis of variance

statistically significant. With comparison restricted to diabetic groups vs control subjects, disregarding correction for multiple testing, both $\mathrm{D}_{2}$ and $\mathrm{D}_{3}$ had a significantly higher diastolic night/day ratio than the control subjects $(p=0.01$ for both). Systolic night/day ratios were not statistically significantly different by analysis of variance.

In $\mathrm{D}_{4}$ the night/day ratio of systolic and diastolic was significantly higher $(97.6 \pm 8.1 \%$ and $93.5 \pm 8.1 \%)$ than in $\mathrm{D}_{3}(90.4 \pm 6.0 \%$ and $86.0 \pm 5.1 \%, p<0.05$ for all $)$. The 24-h ambulatory blood pressures are depicted in Figures 1 and 2. Individual night/day ratios for diastolic blood pressure are shown in Figure 3.

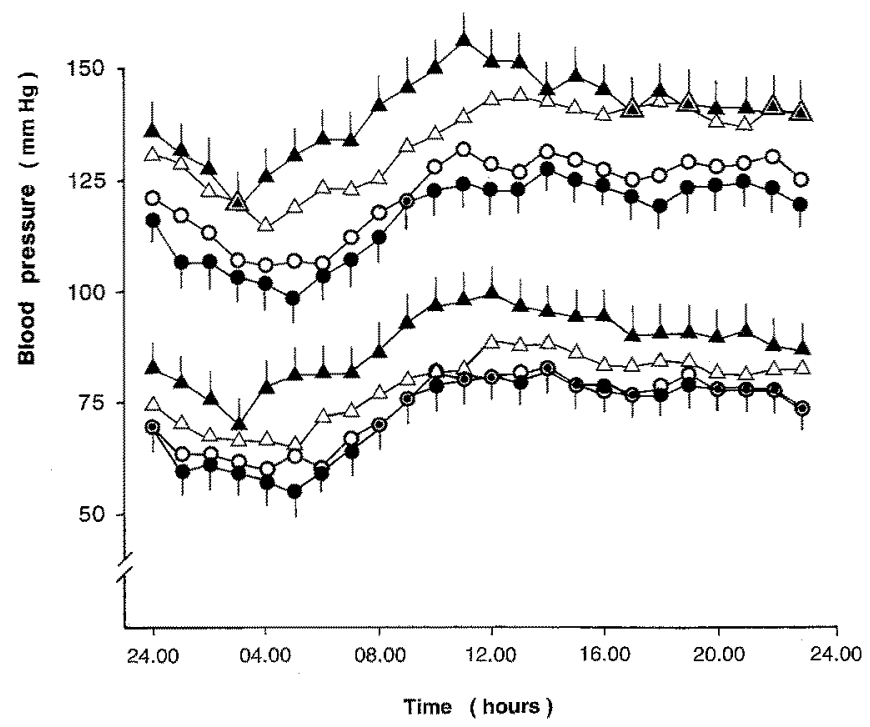

Fig. 1. Twenty-four hour profile of mean systolic and diastolic blood pressure for Type 1 (insulin-dependent) diabetic patients and healthy control subjects. Diabetic patients with nephropathy and without antihypertensive treatment $\left(\mathrm{D}_{3}, n=13\right.$, $\left.\mathbf{\Delta}\right)$; microalbuminuric patients $\left(\mathrm{D}_{2}, n=26, \Delta\right)$; normoalbuminuric patients $\left(\mathrm{D}_{1}\right.$, $n=26,0)$ and control subjects $(C, n=26,0)$. Vertical bars represent standard errors 


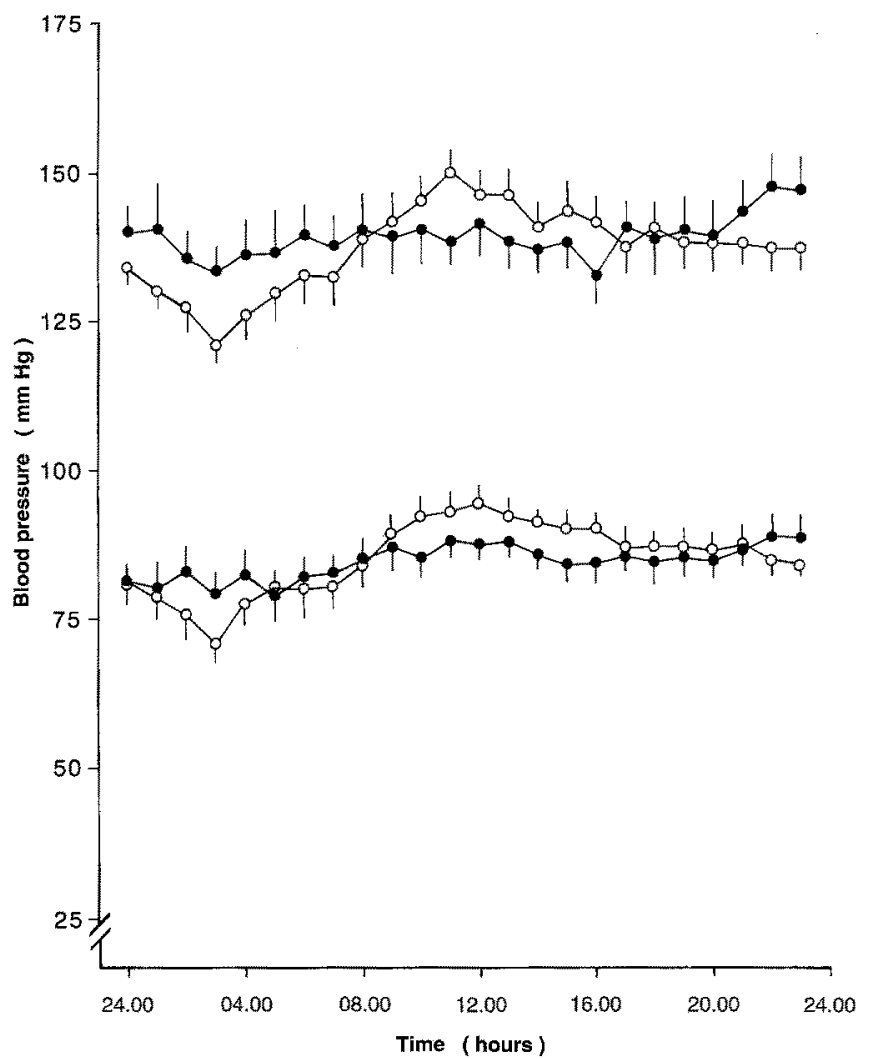

Fig. 2. Twenty-four profile of systolic and diastolic blood pressure for Type 1 (insulin-dependent) diabetic patients with nephropathy and treatment for hypertension $\left(\mathrm{D}_{4}, n=11,0\right)$ or without antihypertensive treatment $\left(\mathrm{D}_{3}, n=13, \mathrm{O}\right)$. Vertical bars represent standard errors

The daytime heart rate increased gradually from $\mathrm{C}$ to $D_{3}$, rendering groups $D_{2}$ and $D_{3}$ statistically different from C. During the night only heart rate in $\mathrm{D}_{3}$ was statistically significantly higher than in C (Table 2 and Fig.4). The heart rates (night or day) in $\mathrm{D}_{3}$ and $\mathrm{D}_{4}$ did not differ significantly.

A multiple stepwise selection was performed in all diabetic patients $(n=76)$ with the diastolic night/day ratio as dependent variable and the following possible independent variables: diabetes duration, age, $\log$ (UAE), 1/serum creatinine, $\mathrm{HbA}_{1 \mathrm{c}}$, 24-h diastolic blood pressure, night heart rate and antihypertensive medication as a dichotomous variable (yes/no). The independent determinants selected were in order of significance: 1) $24-\mathrm{h}$ diastolic blood pressure, 2) night heart rate, 3) antihypertensive medication and 4) $\mathrm{HbA}_{1 \mathrm{c}}\left(r^{2}=0.32, p<0.0001\right.$ for the full regression).

\section{Discussion}

The present group of untreated patients with diabetic nephropathy are heavily biased towards a "normal" blood pressure since for the last 15 years much attention has been paid to nephropathic patients with the purpose of early and effective antihypertensive treatment. Nevertheless, blood pressure in this group of patients was clearly elevated. This disappointing fact may partly be explained

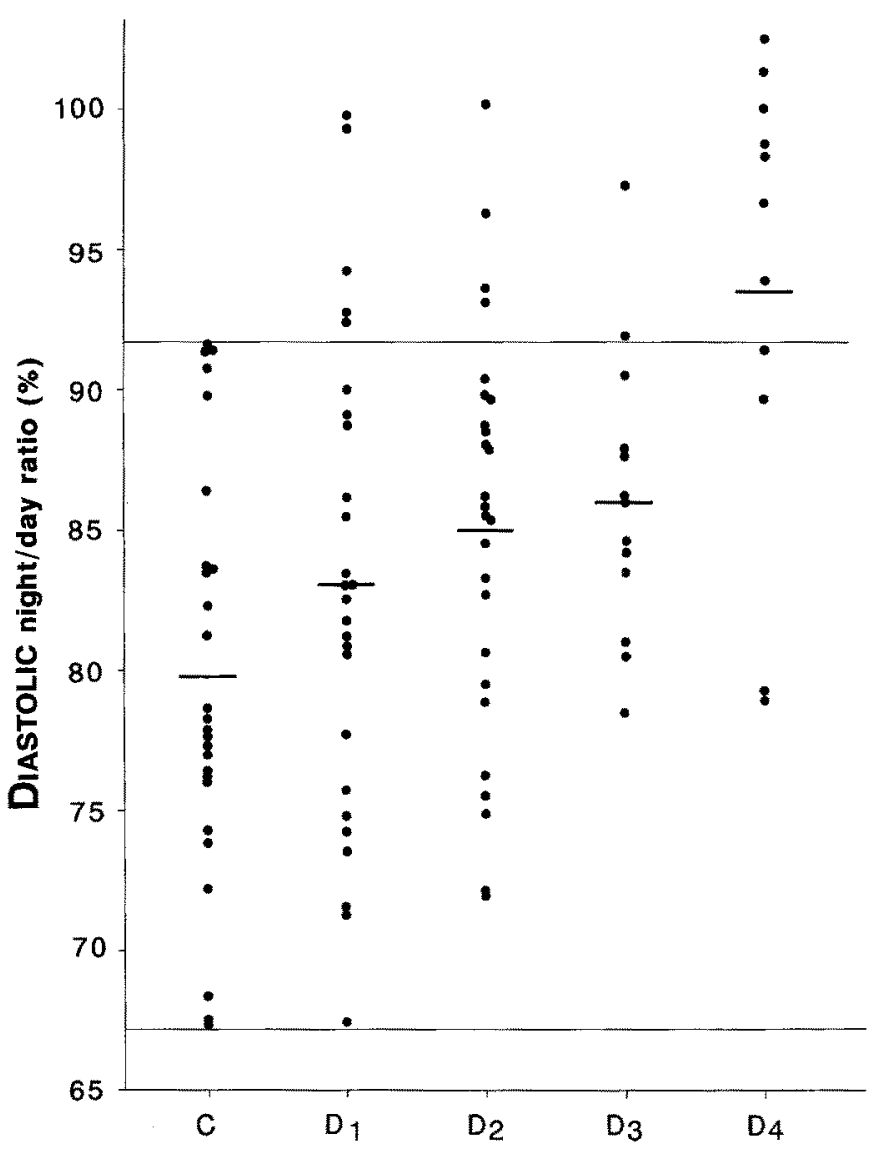

Fig.3. Individual night/day ratio for diastolic blood pressure in healthy control subjects and Type 1 (insulin-dependent) diabetic patients. $\mathrm{C}=$ control subjects $(n=26), \mathrm{D}_{1}=$ normoalbuminuric patients $(n=26), \mathrm{D}_{2}=$ microalbuminuric patients $(n=26), \mathrm{D}_{3}=$ patients with diabetic nephropathy without antihypertensive treatment $(n=13), \mathrm{D}_{4}=$ patients with diabetic nephropathy with antihypertensive treatment $(n=11)$. Horisontal lines indicate the range for control subjects

by poor compliance by some of the patients who were not subjected to regular blood pressure control. Even if a treatment goal of a clinic blood pressure less than $140 / 90 \mathrm{~mm} \mathrm{Hg}$ was actually achieved in the treated group, this is still not considered normalization of blood pressure.

The diurnal blood pressure variation is expressed as the night/day ratio rather than night-day differences which a priori would overestimate the variation in hypertensive patients. A precise evaluation of the diurnal rhythm depends on accurate patient-reported night periods as used in this study. Compared to the nocturnal reduction of diastolic blood pressure in healthy subjects $(\mathrm{C}$, $20 \%$ ) the study indicated a diminished reduction in the microalbuminuric group $\left(\mathrm{D}_{2}, 15 \%\right)$ and the diabetic nephropathy group with no antihypertensive treatment $\left(D_{3}\right.$, $14 \%$ ), although the differences did not reach statistical significance if correction for multiple comparision was applied [18]. In contrast the night reduction of diastolic blood pressure was $7 \%$ in patients with diabetic nephropathy and treatment for hypertension $\left(\mathrm{D}_{4}\right)$. In a study using the same equipment the relative night reduction of the diastolic blood pressure in healthy subjects was $14 \%$, whereas the reduction in a Type 1 diabetic population 


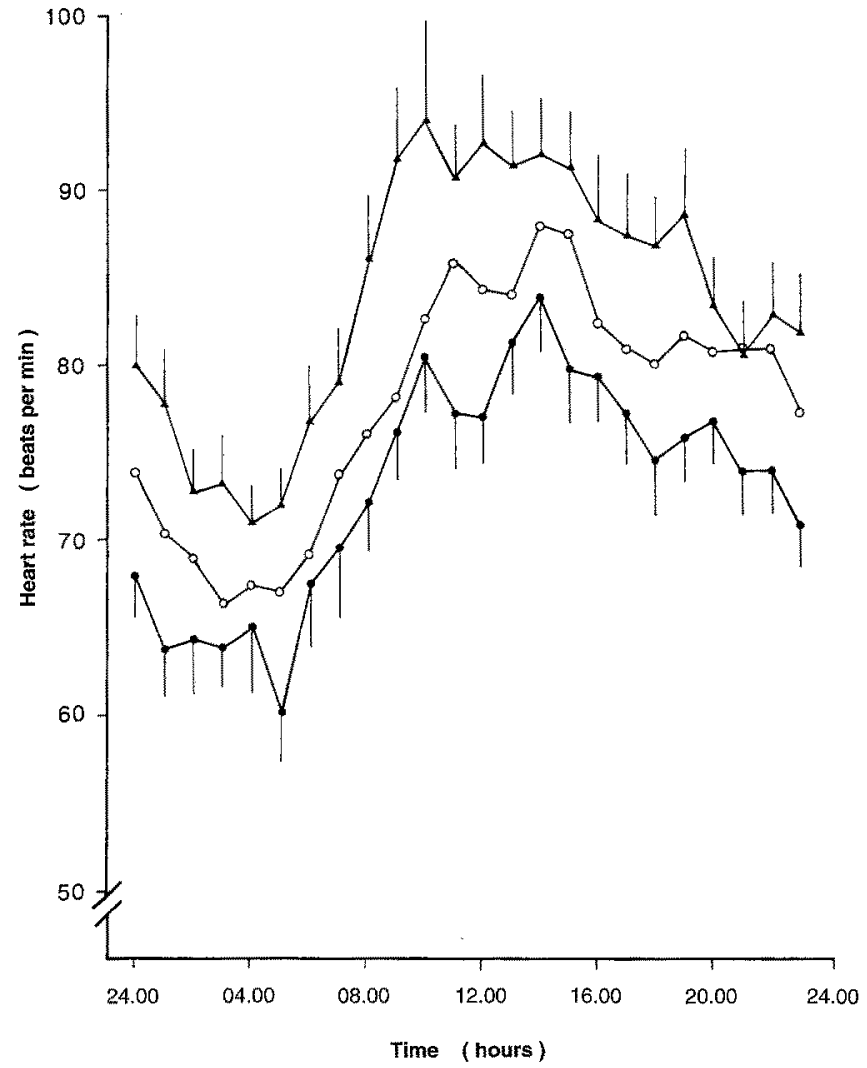

Fig. 4. Twenty-four hour profile of mean heart rate for Type 1 (insulin-dependent) diabetic patients and control subjects. Diabetic patients with nephropathy without antihypertensive therapy $\left(\mathrm{D}_{3}\right.$, $n=13, \mathbf{\Lambda})$; microalbuminuric patients $\left(\mathrm{D}_{2}, n=26,0\right)$; control subjects $(C, n=26,-$ ). Vertical bars represent standard error

with different degrees of UAE was $3 \%$ [19]. The night period was fixed from 22.00 hours to 06.00 hours regardless of when the individual patients actually slept which would tend to minimize the night/day ratio in both groups.

The presence of autonomic neuropathy in diabetic nephropathy in our study is suggested (but not proven by formal test of autonomic function) by the findings of elevated heart rates, most likely the effect of reduced vagal tone $[20,21]$. Interestingly this difference when compared to control subjects is present not only in resting supine position at night, as expected because of the high nocturnal vagal tone in healthy subjects [20], but also during upright position in the day. Such imbalance in cardiac innervation is associated with decreased heart rate variability and increased mortality after myocardial infarction, possibly by predisposing to fatal arrhythmias $[22,23]$. This could explain the added beneficial effect of secondary prophylaxis with metoprolol after myocardial infarction in diabetic patients as compared to non-diabetic individuals $[24,25]$. Against the background of high prevalence of ischaemic heart disease [26] in diabetic nephropathy and the very high cardiovascular mortality [2] the addition of beta ${ }_{1}$ blockers to treatment with ACE-inhibitors and diuretics may be favourable for protection against unopposed sympathetic activity.

The cause of abnormal circadian blood pressure pattern in diabetes is most likely multifactorial. One previous study found loss of the diurnal rhythm in patients specifically selected for the presence of autonomic neuropathy and absence of overt nephropathy [27], suggesting that diabetic nephropathy is not a decisive factor for this $a b$ normality of blood pressure variation. On the other hand a normal blood pressure pattern has been found in $28 \%$ of patients with abnormal cardiovascular reflexes [8] and the prevalence of overt nephropathy was increased four-fold in a group of Type 2 diabetic patients with reversed circadian pattern [28]. Thus, both renal insufficiency and associated fluid retention, as well as autonomic dysfunction may be causually related to the disturbed circadian pattern in patients with advanced diabetic nephropathy. This hypothesis is supported by the results of the multiple stepwise selection from this study, which identified ambulatory blood pressure (itself strongly related to stages of renal disease) and indices of autonomic function (resting night heart rate) as independently influencing the night/day ratio of the diastolic blood pressure. In addition a role for poor metabolic control is suggested. Without withdrawal of medication it is not possible to fully evaluate the impact of the intensive antihypertensive treatment on the blunted diurnal variation of blood pressure. However, it is unlikely that the antihypertensive medication itself primarily induces an abnormal circadian pattern of the blood pressure since this is unaffected in essential hypertension by both ACE-inhibitors and beta-blockers combined with diuretics $[29,30]$. Moreover we have previously reported night/day ratios in patients with early diabetic nephropathy treated with ACE-inhibitors, metoprolol and diuretics which are comparable to the values in the untreated group $\mathrm{D}_{3}$ in the present study [31].

The independent prognostic significance of a blunted diurnal variation in diabetes is difficult to assess because the phenomenon seemingly goes hand in hand with diabetic nephropathy, itself heralding a poor prognosis. Moreover it is well-known that autonomic dysfunction determined by bedside testing $[11,32]$ or by 24 -h assessment of vagal function [20] is more prevalent in patients with incipient or overt nephropathy. Autonomic cardiac dysfunction in diabetic patients has been related to an increased mortality mainly from renal failure [33-35]. It has been speculated that autonomic dysfunction could adversly affect renal function by promoting renal vasodilation and elevated transglomerular hydraulic pressure [36]. In this study, comparing two well-matched groups of insulin-treated diabetic patients with and without autonomic neuropathy, UAE was higher in the former group and significantly so only during the night [36]. The present study suggests the complementary theory, that the coexistence of nephropathy and autonomic neuropathy in addition to a poor metabolic control, could promote an abnormal elevated nocturnal blood pressure with a detrimental effect on renal function.

We conclude that a minor reduction of the diastolic nocturnal blood pressure fall is seen in Type 1 diabetic patients with microalbuminuria or early overt diabetic nephropathy and that major disturbances of the diurnal rhythm are present in the majority of patients with advanced diabetic nephropathy receiving treatment for hypertension. Ambulatory blood pressure monitoring of 
antihypertensive treatment is necessary to achieve 24-h control of blood pressure without side effects.

Acknowledgements. The study was supported by a grant from the Danish Diabetes Association, the research foundation of Aarhus University, the E. Hartelius and the V. and T.Foersom Foundation. S.M.Marshall held a British Medical Research Council Travelling Fellowship.

\section{References}

1. Andersen AR, Sandahl Christiansen J, Andersen JK, Kreiner S, Deckert T (1983) Diabetic nephropathy in type 1 (insulin-dependent) diabetes: an epidemiological study. Diabetologia 25: 496-501

2. Borch-Johnsen K, Kreiner S (1987) Proteinuria: value as predictor of cardiovascular mortality in insulin-dependent diabetes mellitus. Br Med J 294: 1651-1654

3. Mogensen CE (1982) Long-term antihypertensive treatment inhibiting progression of diabetic nephropathy. Br Med J 285: 685688

4. Parving H-H, Smidt UM, Andersen AR, Svendsen PAa (1983) Early aggressive antihypertensive treatment reduces rate of decline in kidney function in diabetic nephropathy. Lancet I: 11751179

5. Mathiesen ER, Borch-Johnsen K, Jensen DV, Deckert T (1989) Improved survival in patients with diabetic nephropathy. Diabetologia 32: 884-886

6. Walker JD, Dodds RA, Murrells TJ et al. (1989) Restriction of dietary protein and progression of renal failure in diabetic nephropathy. Lancet II: 1411-1415

7. The National High Blood Pressure Education Program Coordinating Committee (1990) National high blood pressure education program working group report on ambulatory blood pressure monitoring. Arch Intern Med 150:2270-2280

8. Liniger C, Favre L, Assal J-Ph (1991) Twenty-four hour blood pressure and heart rate profiles of diabetic patients with abnormal cardiovascular reflexes. Diabetic Med 8: 420-427

9. Liniger C, Favre L, Adamec R, Pernet A, Assal J-Ph (1987) Profil nycthéméral de la pression artérielle et de la fréquence cardiaque dans la neuropathie diabétique autonome. Schweiz Med Wschr 117: 1949-1953

10. Chanudet X, Bauduceau B, Ritz P et al. (1989) Neuropathie végétative et régulation tensionnelle chez le diabétique. Arch Mal Cæur 82: 1147-1151

11. Zander E, Schulz B, Heinke P, Grimmberger E, Zander G, Gottschling HD (1989) Importance of cardiovascular autonomic dysfunction in IDDM subjects with diabetic nephropathy. Diabetes Care 12:259-264

12. Mogensen CE (1987) Microalbuminuria as a predictor of clinical diabetic nephropathy. Kidney Int 31: 673-689

13. Hansen KW, Christensen CK, Andersen PH, Mau Pedersen M, Sandahl Christiansen J, Mogensen CE (1992) Ambulatory blood pressure in microalbuminuric type 1 diabetic patients. Kidney Int 41: $847-854$

14. Parving H-H, Hommel E, Smidt UM (1988) Protection of kidney function and decrease in albuminuria by captopril in insulin dependent diabetics with nephropathy. Br Med J 297: 1086-1089

15. O'Brien E, Mee F, Atkins N, O'Malley K (1991) Evaluation of the Spacelabs 90202 according to the AAMI standard and BHS criteria. J Hum Hypertens 5: 223-226

16. Christensen CK, Ørskov C (1984) Rapid screening PEG radioimmunoassay for quantification of pathological microalbuminuria. Diabetic Nephropathy 3:92-94

17. Engbaek F, Christensen SE, Jespersen B (1989) Enzyme immunoassay of hemoglobin $A_{i c}$ : analytical characteristics and clinical performance for patients with diabetes mellitus, with and without uremia. Clin Chem 35: 93-97

18. O'Brien PC (1983) The appropriateness of analysis of variance and multiple-comparison procedures. Biometrics 39: 787-794
19. Wiegmann TB, Herron KG, Chonko AM, Macdougall ML, Moore WV (1990) Recognition of hypertension and abnormal blood pressure burden with ambulatory blood pressure recordings in type 1 diabetes mellitus. Diabetes 39: 1556-1560

20. Mølgaard H, Christensen PD, Sørensen KE, Christensen CK, Mogensen CE (1992) Association of 24-h cardiac parasympathetic activity and degree of nephropathy in IDDM patients. Diabetes 41: 812-817

21. Ewing DJ, Borsey DQ, Travis P, Bellavere F, Neilson JMM, Clarke BF (1983) Abnormalities of ambulatory 24-hour heart rate in diabetes mellitus. Diabetes 32: 101-105

22. Kleiger RE, Miller JP, Bigger JT, Moss AJ, the Multicenter Postinfarction research group (1987) Decreased heart rate variability and its association with increased mortality after acute myocardial infarction. Am J Cardiol 59: 256-262

23. Cripps TR, Malik M, Farrel TG, Camm AJ (1991) Prognostic value of reduced heart rate variability after myocardial infarction: clinical evaluation of a new analysis method. Br Heart J 65 : $14-19$

24. Malmberg K, Herlitz J, Hjalmarson $\AA$, Ryden L (1989) Effects of metoprolol on mortality and late infarction in diabetics with suspected acute myocardial infarction. Retrospective data from two large studies. Eur Heart J 10: 423-428

25. Kjekshus J, Gilpin E, Cali G, Blackey AR, Henning H, Ross J Jr (1990) Diabetic patients and beta-blockers after acute myocardial infarction. Eur Heart J 11: 43-50

26. Jensen T, Borch-Johnsen K, Kofoed-Enevoldsen A, Deckert T (1987) Coronary heart disease in young type 1 (insulin-dependent) diabetic patients with and without diabetic nephropathy: incidence and risk factors. Diabetologia 30:144-148

27. Hornung RS, Mahler RF, Raftery EB (1988) Ambulatory blood pressure and heart rate in diabetic patients: an assessment of autonomic function. Diabetic Med $6: 579-585$

28. Nakano S, Uchida K, Kigoshi T et al. (1991) Circadian rhythm of blood pressure in normotensive NIDDM subjects. Its relationship to microvascular complications. Diabetes Care 14: 707-711

29. Meijer JL, Ardesch HG, van Rooijen JC, de Bruijn JHB (1986) Low dose captopril twice daily lowers blood pressure without disturbance of the normal circadian rhythm. Postgr Med J 62 [Suppl 1]: 101-105

30. Kieso HA, Gould BA, Mann S, Hornung RS, Altman DG, Raftery EB (1983) Effect on intra-arterial blood pressure of slow release metoprolol combined with placebo or chlorthalidone. $\mathrm{Br}$ Med J 287:717-720

31. Mau Pedersen M, Hansen KW, Schmitz A, Sørensen K, Christensen CK, Mogensen CE (1992) Effects of ACE-inhibition supplementary to beta blockers and diuretics in early diabetic nephropathy. Kidney Int 41: 883-890

32. Dyrberg T, Benn J, Sandahl Christiansen J, Hilsted J, Nerup J (1981) Prevalence of diabetic autonomic neuropathy measured by simple bedside tests. Diabetologia 20: 190-194

33. Ewing DJ, Campbell IW, Clarke BF (1976) Mortality in diabetic autonomic neuropathy. Lancet I: 601-603

34. Ewing DJ, Campbell IW, Clarke BF (1980) The natural history of diabetic autonomic neuropathy. Quart J Med 49:95-108

35. O'Brien IA, McFadden JP, Corrall RJM (1991) The influence of autonomic neuropathy on mortality in insulin-dependent diabetes. Quart J Med 79: 495-502

36. Winocour PH, Dhar H, Anderson DC (1986) The relationship between autonomic neuropathy and urinary sodium and albumin excretion in insulin-treated diabetics. Diabetic Med 3: $436-440$

Received: 22 April 1992

and in revised form: 13 July 1992

Dr. K.W.Hansen

Medical Department M (Diabetes and Endocrinology)

Aarhus Kommunehospital

DK-8000 Aarhus C

Denmark 